Onur Ender Aslan

University of Ankara

e-mail: aslanonurender@gmail.com

https://doi.org/10.18485/ai_savremeni_roman.2020.ch4

821.163.41.09 Андрић И.

930.85(497.15)"14/18"

Оригинални научни рад

\title{
COMPARATIVE ANALYSES OF 'DEVSHIRME' SYSTEM IN IVO ANDRIÇ’S NOVEL THE BRIDGE ON THE DRINA BASED ON BUREAUCRATIC FACTS OF TURKISH HISTORY
}

In the Ottoman Cihan (Universe) State, especially during the reign of Murat II and Fatih Sultan Mehmet Han, a 'devshirme' system was established. The devshirme method was the main tool for the establishment of a professional bureaucracy in the Ottoman Cihan (Universe) State. Ivo Andriç's monumental novel, the Bridge on the Drina, describes the system of 'devshirme' in Chapter II quite elaborately. In this paper, the part of Ivo Andriç's book, which describes the system of devshirme in a literary language, will be examined in the light of Turkish bureaucratic history

Key Words: Ivo Andrić, Bridge on the Drina, Serbian novel, historical novel, Serbian history, Turkish history.

Ivo Andric's monumental novel entitled the Bridge on the Drina is one of the most well-known novels in Turkey for the Balkan literature (Kolcu, 2003; Bayram, 2014; Demir 2016). Today, two of the Balkan scholars/writers are quite popular in Turkey; one being Ivo Andric and the other, Mesha Selimovic, both hailing from former Yugoslavia and born in Bosnia and Herzegovina. In this paper, I will discuss 
whether the 'devshirme' system described in the novel matches with the historical facts and how it is depicted to the readers from the perspective of public administration.

In the second chapter of his novel, the Bridge on the Drina, Ivo Andric describes the 'devhsirme' system eloquently in a literary language. The way the devshirme system is explained in the novel is moving. According to Andriç, the 10-15 year-old children were taken away from their families who were then converted to Islam, duly circumcised. They either served as janissaries in the Ottoman army or were appointed to higher ruling positions in the state.

In this chapter, he analyzes the devshirme system by giving the example of the Grand Vizier Sokullu Mehmet Pashawho gave the order to have the Drina Bridge built. Since the main hero and hence the title of the novel is the bridge, it is not very clear why the 'devshirme' system is explained in the novel. But, the Grand Vizier Sokullu Mehmet Pasha and the real architect of the bridge, Mimar Sinan, were devshirmes. In addition, Andric also included the feelings of the devshirme child in the person of Sokullu Mehmet Pasha. He even describes the child's feelings in a rather epic and lyrical way.

However, after the second paragraph, Andriç, in the person of Sokullu Mehmet Pasha, describes the later life of these devshirmes. At this point, breaking from earlier emotional language, Andriç adopts a purely rational and even result-oriented narrative. He underlines that devshirmes are appointed to high positions in the state and run a global state. When he writes, "the world knows them better than we do", emotions changed direction and one can observe that there was a transition from sadness to pride along Andriç's lines. 
According to Andriç, the construction of the famous bridge over Drina by Sokullu Mehmet Pasha is a direct result of this pride and the power within. The mighty grand vizier is doing this as he feels a duty to help out and develop his ancestral land. By doing this, the Grand Vizier feels that he paid his debt to the land he came from. He also havean inn (Han-Hotel) built next to the bridge where it was free to stay for any traveler for the next 300 years. All expenses were covered by the Grand Vizier's Foundation (Vakf) withincome incurring from Ottoman's Hungary Province territory. Andriç described the bridge as a service of a high ranking Ottoman bureaucrat raised by this land. This explanation can be seen in many passages in the novel. At the end of the book, on the other hand, he compares the recruitment of the Austrian state from Bosnia to the devshirme system.

It should be noted that Ivo Andriç's perspective and narratives have influenced historical view especially in Serbia. Andric's narrative is taken as a reality. We can see an example of this in the picture in the Serbian high school textbook. The picture is based on Andric's narration.

Devshirme, also known as the blood tax or tribute in blood, was chiefly the practice where the Ottoman Universe State sent officers to take mostly Orthodox boys, ages 8 to 15, from their families in Balkans and Anatolia in order that they be raised to serve the state. Theywere not slaves (Koçu, 2015).

First Step: Collecting boys from their families. The rule was to get a child in every 40 families. There were cases when some families offered their children voluntarily to the Empire as it opened them prospects which were not available in any other manner.

Second Step: These children were then brought to Edirne and Istanbul and given to Muslim families and subsequently converted to Islam. 
Third Step: Out of the children who were converted to Islam, a selection was made based on the best and fittest both physically and mentally. The best were then sent to the madrasas (schools) for learning whereas the others were handed to the guild of janissaries or Ottoman military units.

Fourth Step: The best children were taken to Enderun, the Palace School, in the Topkapi Palace where they received at least 10 years of university education. Those who finished the Enderun School would be raised as high-ranking rulers and served next to the Sultan (Aslan, 2019). So, the devshirme system in the Ottoman Empire was feeding the ruling (elite) class of the state. The establishment of such a professional bureaucracy was based on two main certain characteristics:

1) Loyalty and,

2) Meritocracy.

In addition to these, it was not inherent or ascribed status but rather an achieved position. Therefore, the children of devshirmes could not be devshirmes.

Finally, here is my general assessment of devshirme system. The Ottoman State was essentially a universe state and global power between the $15^{\text {th }}$ to $17^{\text {th }}$ Century. There were two main regions of the Ottoman Universe State, the first was Anatolia and the second was the Balkans. Therefore, the Ottoman Universe State was founded on two pillars. More than half of the Ottoman Grand Viziers, namely Prime Ministers, were of Balkan origin and devshirme. Therefore, the top level bureaucrats of the Ottoman Universe State were mostly devshirme. Until the 18th century, the person who was not devshirme could not be the top-level bureaucrat. Ivo Andriç also made this clear in his book. The most important result and reality of this situation is that the Ottomans made their 
biggest investments and infrastructure in the Balkans, such asbridges, roads, hammams and mosques. But in my opinion, large development projects in Balkans at the time were made for mainly rational reasons, not because of the emotional connection of the top managers to the region. For example, the Drina bridge was built due to the strategic goals of the Ottoman Universe State.

The devshirme system described by Ivo Andric essentially coincides with the mainstream historical documents in an interesting way. However, historians have not been able to reconcile whether the devshirme system is forced or consensual. In any case, the devshirme system had a large impact on how Ottomans were imagined by the Balkan people and as we can see from the novel itself, there is usually a two sides of the same story: one is that devshirme system was evil and devastating for the families, and the other is that devshirmes became top-level bureaucrats and served the interests of the Ottoman Universe State as well as the region they came from.

\section{BIBLIOGRAPHY}

Andriç, Ivo (2015). Drina Köprüsü, Trans. N. Müstakimoğlu H.A. Ediz, İstanbul: İletişim.

Aslan, Onur Ender (2019). Devlet, Bürokrasive Kamu Personel Rejimi [The State, Bureaucracy and Public Personnel Regime], 3rd Publication, Ankara: İmge Publishing House. Bayram, Sibel (2014). "Ivo Andriç' in Drina Köprüsü Adlı Romanı Bağlamında Hayatlara Uzanan Köprüler”, Turkish Studies, pp. 271-282.

Demir, Musa (2016). "Ivo Andriç’ in Drina Köprüsü Adlı Roman ın da Osmanlı Algısına Genel BirBakış", Avrasya Etüdleri, pp. 453-470.

Koçu, ReşadEkrem (2015). Yeniçeriler [Janissaries], İstanbul: DK. 
Kolcu, Abdurrahman (2003). "Ivo Andriçve Drina Köprüsü Romanı", TÜBAR, pp. 219-245.

\section{Онур Ендер Аслан}

\section{КОМПАРАТИВНА АНАЛИЗА ЈАҢИЧАРСКОГ СИСТЕМА У АНДРИЋЕВОМ РОМАНУ \\ На Дрини ћуприја и бирократске чињенице турске историје}

\section{Сажетак}

У Отоманској држави, нарочито у време Мурата II и Фатих Султана Мехмета Хана, успостављен је систем „данка у крви“. Метода овог система била је главно средство професионалне бирократије у отоманској држави. Монументални роман Иве Андрића На Дрини ћуприја описује овај систем. У раду ће романсирана слика овог система бити упоређена са турским историјским подацима.

Кључне речи: Иво Андрић, На Дрини ћуприја, српски роман, историјски роман, српска историја, турска историја. 